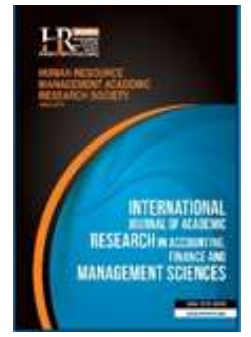

International Journal of Academic Research in Accounting, Finance and Management Sciences

Vol. 10, No.1, January 2020, pp. 172-188

E-ISSN: 2225-8329, P-ISSN: 2308-0337

(C) 2020 HRMARS

www.hrmars.com

To cite this article: Anidiobu, G.A., Paschal Okolie, P.I.P., Onyia, C.C., Onwumere, J.U.U. (2020). Impact of Foreign Capital Inflow on Economic Growth in Ecowas Sub-Region, International Journal of Academic Research in Accounting, Finance and Management Sciences 10 (1): 172-188

\title{
Impact of Foreign Capital Inflow on Economic Growth in Ecowas Sub- Region
}

\author{
Gabriel A. Anidiobu ${ }^{1}$, Paschal I.P. Okolie ${ }^{2}$, \\ Chinedu C. Onyia ${ }^{3}$, Josaphat U.J. Onwumere ${ }^{4}$ \\ ${ }^{1,2,3}$ Department of Banking \& Finance, Enugu State University of Science \& Technology (ESUT), Enugu, Nigeria \\ ${ }^{4}$ Department of Banking \& Finance, University of Nigeria, Enugu Campus, Enugu, Nigeria
}

\begin{abstract}
This study assessed the impact of external finance (proxied by external debt) on economic growth (measured by real GPD growth rate) in Economic Community of West African States (ECOWAS) sub-region. Annualized panel data for 32 years (1986-2017) were obtained from World Development Indicators (WDI). Ex-post facto design was adopted because our data were secondary in nature. Individual characteristic of the series were ascertained with descriptive statistics. The stationarity of our variables was tested using five test criteria, namely: Levin, Lin \& Chu t; Breitung t-stat; Im, Pesaran and Shin W-stat; ADF-Fisher Chi-square, and PP-Fisher Chi-square. The panel series became stationary when differenced at first [(i.e. at order one I(1)], which proved that our panel series did not have unit root. Panel least square (PLS) estimation process was used to analyze our modified models. The model were further analyzed with both fixed and random effect panel regression estimators, using the Hausman test to ascertain the best and appropriate choice between the two. Thus, our analysis was based on the random effect (RE) estimator. A 5\% error tolerance level was allowed for this study. The outcomes showed external debt had a negative, but significant effect on real GDP growth rate. The implication was that external debt did not enhance economic growth in the sub-region during the sample period. This outcome was attributed to ineffective fiscal policy implementations and lack of budget discipline. Since external debt is noteworthy debt instrument that can help boost the economies of ECOWAS countries, governments of the sub-region must adopt fiscal adjustment mechanisms that can enhance their revenue profiles through improved taxes rather than borrowing to finance deficit and total reliance on primary commodities (usually unprocessed e.g. crude oil, cocoa) for revenue. The major contribution of this study to knowledge was that it made comparative analysis using outcomes of the sub-regional study and the countryspecific outcomes of the 15 member countries of ECOWAS employing modified panel regression models to analyze the research objective.
\end{abstract}

Key words External Finance, External Debt, Real Gdp Growth Rate, Panel Least Square, Ecowas Sub-Region

\begin{tabular}{|c|c|c|}
\hline Received: & 19 Feb 2020 & (c) The Authors 2020 \\
\hline Revised: & 28 Feb 2020 & Published by Human Resource Management Academic Research Society (www.hrmars.com) \\
\hline ccepted: & 01 Mar 2020 & This article is published under the Creative Commons Attribution (CC BY 4.0) license. Anyone may \\
\hline ned Online: & 20 Mar 2020 & $\begin{array}{l}\text { reproduce, distribute, translate and create derivative works of this article (for both commercial and } \\
\text { non-commercial purposes), subject to full attribution to the original publication and authors. The full } \\
\text { terms of this license may be seen at: http://creativecommons.org/licences/by/4.0/legalcode }\end{array}$ \\
\hline
\end{tabular}

\section{Introduction}

Capitals move into a country or region in form of diaspora or personal remittances from African migrants; foreign direct investment (acquisition of companies, security trading); official development assistance (funding offered by governments or aid agencies to disadvantaged countries either free of charge or at rates below the market rate), and foreign or external debt (a fallout for borrowing from abroad). Sub-Saharan Africans, sub-regions e.g. ECOWAS and other developing countries harness these 
funding programmes to bridge their saving-investment and foreign exchange gaps occasioned by inadequate domestic resources and trade imbalances respectively.

Developing African countries leverage more in external capital than any other continent across the globe. For instance, over time, sub-Saharan African (SSA) has received over US\$568 billion in foreign capital inflows, which projected to be 15 per cent of Africa's gross domestic product (Ezeaku et al., 2017). FCls if well managed can promote macroeconomic performances of the recipient countries or regions. As a result, this concept is giving rise to concern over the magnitude, causes and consequences of these continuous resource inflows. Taking the modes of $\mathrm{FCl}$ delivery into account, external debt seems most applicable; hence captures the specific focus of this paper. Bearing in mind that available local resources are scarcely enough for African countries to pursue envisaged macroeconomic goals, Akanni (2014) observes the need to acquire external resources to support the growth agenda was pursued vigorously by attracting foreign investment and through direct borrowing by governments to augment domestic resources for investment. This marked the beginning of external debt accumulation by these countries, and the consequent burden it has constituted over the years, which has attracted serious concern from the international community ... The implication is scarcity of resources in the sub-region is being further compounded by the flight of capital.

Since external borrowing seems to be the norm among ECOWAS countries, the dominant question in development finance literature is whether the escalating capital inflows have translated to desired macroeconomic turnarounds. Foreign capitals can drive growth and development in a number of ways: (1) Foreign capital promotes investments in productive and human capital; (2) it improves capacity of the borrowing economies to import capital goods and technology, and (3) it facilitates the process of technology transfer, which guarantees sustained increase in productivity, innovation and technical change (Ekanayake \& Chatrna, 2010). Critics of foreign capital argue that factors that influence a country's development face serious obstacles attributed to institutional failures and poor governance. This assertion implies that external finance produces desired result if combined with effective control of governance (Ezeaku et al., 2017). In contemporary African society, progressive corrupt practices, lack of accountability and weak operational institutions seem to be the norm rather than the exception. Owing to irreconcilable nature of foreign capital effectiveness and the perceived institutional influence on foreign finance management, we become inclined to review impact of capital inflows (particularly, external debt) on growth rate of ECOWAS sub-region.

Country-specific studies focusing on debt-growth nexus are many; comparing the number with regional based studies of this phenomenon may be exaggerated and unconvincing. As a result, there could be unevenness of emphasis in the extant literature regarding studies of the two categories. In our opinion, there is a bias in support of the former. On account of that, this study had been expanded to sub-regional level in order to ascertain the extent exposure to imported finance had compromised economic stability in ECOWAS sub-region as a unit throughout the study period. Thus, the problem of study involved (1) need to update the panel data used for analysis than was previously available; ((2) make comparative analysis using outcomes of the sub-regional study and the country-specific outcomes of 15 member countries of ECOWAS employing modified panel regression models to analyze the research objective. Ultimately, this study would affirm or contradict existing works in this area. This is particularly necessary for policy analysis considering efforts toward sub-regional integration. With this motivation, our zeal to embark on this research at this time was aroused.

The scope of this paper covered 1986-2017. Reason for using 1986 as base year of research was because Nigeria being the biggest economy in the sub-region introduced the Structural Adjustment Programme (SAP) in 1986. Another reason was that other countries in ECOWAS bloc were reformed and became more outward looking with SAP launched about the same time as Nigeria. The key objectives of SAP can be summarized as: (i) minimizing state intervention in the economy; (ii) establishing a free market economy (iii) integrating the economy with the global economic system. This liberalization process through liberalized import regime, new foreign investment and export promotion policies have repositioned ECOWAS countries to take their place among the world economy, and so on.

The map of Africa here is meant to provide an overall geographic impression of the continent, and delineate the 15 member ECOWAS countries visually captured in figure 1: 


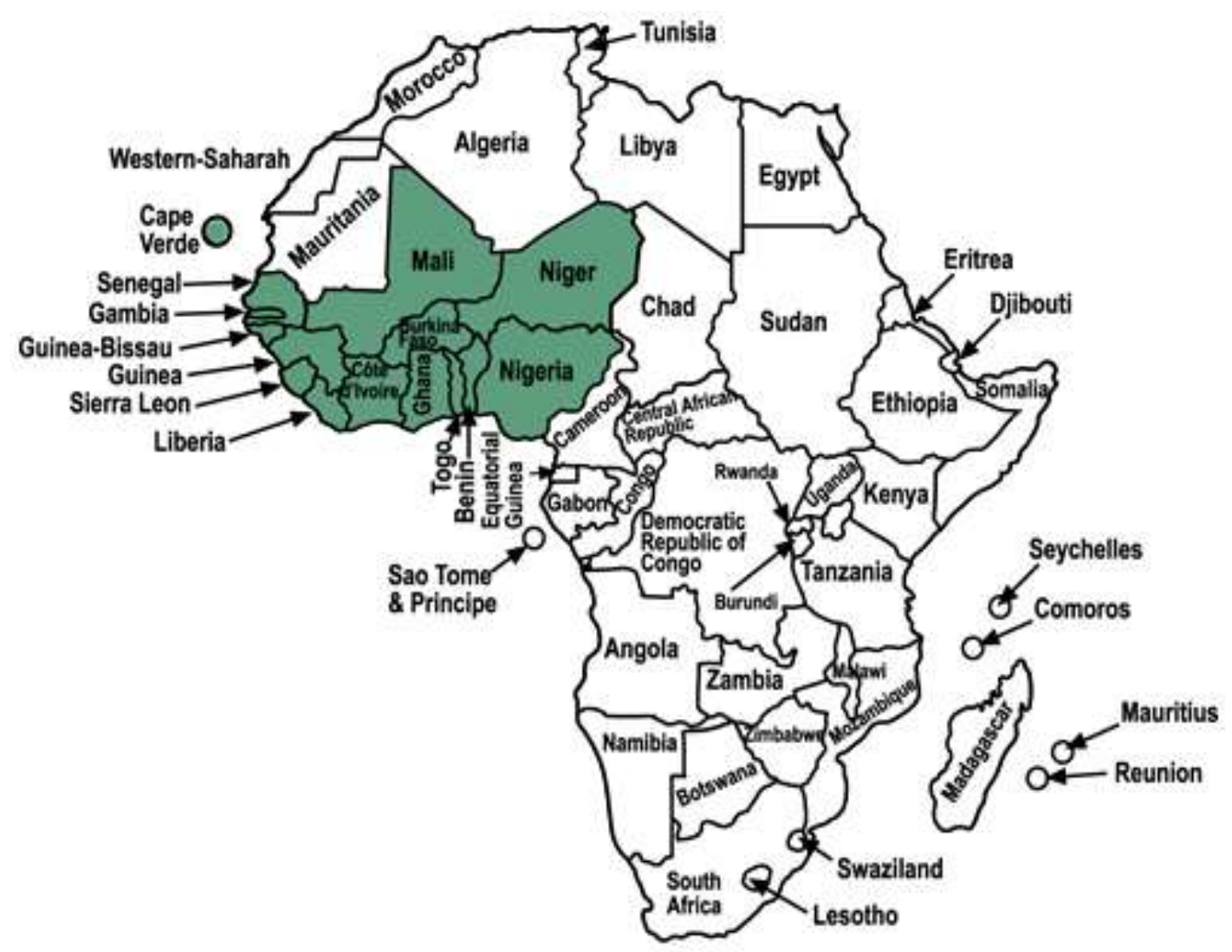

Figure 1. Map of Africa showing a-fifteen (15) Member ECOWAS Sub-region

Source: World Economic Indicator

This paper was chiefly limited by our inability to access some relevant secondary data of some of the ECOWAS countries. Admittedly, the data obtained from Development Indicators as published by the World Bank for 32 years (1986-2017) could contain some measurement errors that would likely affect the robustness of our findings. Furthermore, this study failed to factor in other avenues of external capital to the sub-region other than external debt. External debt remains an aspect of foreign capital flows; therefore, it is expected that further researches will be directed to the other modes of delivery.

\section{Literature review}

\subsection{Conceptual review}

There are concepts that define the broad and specific objective of this work. These concepts are foreign capital inflow $(\mathrm{FCl})$, particularly external debt, which as a funding instrument encompasses diverse dimensions of obligation. However, our emphasis envisions direction of causality between the variables that make up our study objective. The relevant terms are conceptualized hereunder:

\subsubsection{Foreign Capital Inflow}

The 'foreign' component of our research title refers to any business, person or entity outside of the domestic economy. 'Capital' in this context is money available for investment by governments, businesses or individuals. It includes highly liquid assets like cash and credit. It also includes non-liquid assets like stocks, real estate and high-interest loans. Large financial institutions that make most investments prefer using borrowed money. 'Inflow' signifies money moving into the economy. Foreign capital denotes capital flows from resident entity of one country to the resident entity of another country. The resident entity may be an individual, company or a government. Above all, foreign capital inflow ( $F C l)$ refers to increase in quantum of money moved from foreign sources to a country or region not only to achieve economic 
growth, but enhance overall macroeconomic performance of the country or region as well. External debt, one of the sources of $\mathrm{FCl}$ serves as proxy.

\subsubsection{External debt}

The Dictionary of Banking and Finance (2005) defines external debt "as money which a company has borrowed from outside sources (such as a bank) as opposed to money raised from shareholders." This definition brings up three salient points: (1) external debt is money needed by a person, business organization or country, which it lacks; (2) the money (debt) must come from anywhere beyond the boundary of the borrower (for a country across national frontiers) where a capable and willing lender is located; (3) the principal must be paid off plus interest charges in conformity with the lender's terms because the lender in this context is not a charity, and (4) the borrower in line with (4) above must demonstrate substantial capacity to commit the debt to viable project(s) that could finance the obligation as per the loan agreement.

External debt in this context relates to a country's indebtedness to foreign lenders. It can be conceptualized as the fraction of a country's debt that is borrowed from foreign creditors including governments, commercial banks and international financial institutions. Typical examples of such financial institutions are the International Monetary Fund (IMF) and the World Bank. Borrowing charges (interests) that add up to the credit facility must be paid back in the currency in which the loan was approved. In order to deserve the agreed loan, the borrowing country may be required to sell and export goods equal in value to the credit facility okayed by the creditor country(s). Total external debt consist the external debt of all tiers of government, and private debt issued by private enterprises.

In addition, Adejuwon et al. (2010) refer to external debt as debt owed by the public and private sectors in ECOWAS countries to foreign interest groups: official and private, which must be repaid (principal and interest) in the currency of the lender country. Also, Onyekwelu et al. (2014) define external debt as an amalgam of claims against the government of a country held by public or private sector of a foreign economy, which may be interest or non-interest bearing. In view of the traditional approach that supports foreign capital as 'cornerstone' to investment and economic development, coupled with declining revenue from export and refusal of the developed world to meet their moral financial obligations to the Third World countries (West African countries inclusive), the latter have to rely on foreign loans (Aluko \& Arowolo, 2010). External or foreign debt constitutes one portion of public debt, while the other portion is domestic debt, which is excluded from this study because it is not within the boundary of international finance (Esezobor, 2009). Foreign borrowing places a charge on the country's future earnings in foreign exchange through debt service and principal repayment.

Akanni (2014) identifies internal and external factors as being responsible for huge external debt situation of SSA countries. The internal factors regarded as macroeconomic policy errors, include mismanagement, high budget deficit, wrong exchange rate policies and corruption. Factors such as stagnation in industrial countries, high foreign interest rates, dwindling terms of trade, strife, and drought are identified as external factors. In spite of that, Obiechina and Ukeje (2013) maintain that every developing economy requires an increased investment propelled by domestic savings, which hitherto is hardly enough to support meaningful national development, and for this reason external debt becomes an unavoidable financing alternative. Developing economies that suffer from deficit budgetary process, low investment returns, dwindling export revenue, and downturns can seek foreign finance in order to improve economic activities and stabilize their macroeconomic variables (Gohar et al., 2012; Osinubi \& Olaeru, 2006). The works of other numerous foreign debt advocates (Raheem \& Adeniyi, 2015; Sulaiman \& Azeez, 2012) are noteworthy.

Governments borrow to buy goods and services that improve welfare of the citizenry and promote economic growth. External debt enables governments of developing countries to facilitate growth take-offs by investing in a critical mass of infrastructures when taxation is overstretched, or when the alternative would be to print money and risk macroeconomic instability. For this reason, external debt is usually delivered based on the purpose, or the need that gives rise to the debt. The various decisions upon which acquisition of external debt is anchored are summarized as follows: 
a. Trade debt - a credit obligation created from a country's inability to repay its import bills. When such debts await settlement beyond one year, they become trade arrears debt, because they are not owed for current year trade but for trade done in previous years.

b. Balance of payment support loan - a financial obligation acquired by a country to improve the status of its balance of payment usually sourced from IMF and other international financial institutions. Balance of payments (BOP) differentiates between a country's total payments and receipts from international trade in goods, services and financial transactions over a specified timeframe, usually one year.

c. Project-tied loan - obtained mainly to bankroll particular projects in the debt seeking country.

d. Loans for social infrastructures - procured in a bid to provide social infrastructures (e.g. education, healthcare, road construction) in a country.

e. Budget deficit support loan (ways and means advances) - short-term government debt meant to make up budget deficits often sourced internally rather than externally. When projected government revenue is less than projected expenditure, the budget is said to be in deficit; the government has to seek financial support, mainly from the Central Bank to make up the difference in revenue.

Most external debts arise from promissory notes and bills of exchange issued in the course of international trade, while others come either as bilateral or multilateral loans. Unlike domestic debts, external debt instruments are not many, but they usually involve very substantial amounts. When the government borrows to finance its activities it creates a burden on the economy, which is ultimately borne by taxpayers and the entire economy. These burdens come in form of interest payment, principal repayment, suppression of private investment and burden transfer to future generation. In determining external debt stock and its burden in a country, the Central Bank and debt management agencies concentrate on two major indicators of debt burden such as:

(i) Ratio of external debt stock to exports: This ratio relates external debt stock to exports because exports provide the foreign exchange needed to service and pay off external debts. This ratio is calculated by dividing external debt stock by total value of exports. It indicates the value of exports the country requires to cover its external borrowings.

(ii) Ratio of external debt service to exports: This ratio measures the proportion of a country's foreign exchange receipts from exports required to service foreign debt. It is measured by dividing the value of external debt services by total exports. The higher this ratio, the less desirable further borrowing will be. This ratio is used for determining external debt burden.

\subsubsection{Real Gross Domestic Product Growth Rate (RGDPGR)}

Real GDP growth rate indicates the rate at which a country's GDP changes or grows from one year to another. It also evaluates how quick the economy improves by drawing comparison between one quarter of the country's GDP and the previous quarter. Real GDP, on the other hand, is an inflation-adjusted macroeconomic assessment which reveals the monetary worth of total goods and services produced by an economy at a particular period expressed in base-year prices, usually regarded as "co," "inflationcorrected" GDP or "constant naira GDP." Unlike nominal GDP, real GDP or growth rate assesses changes in price level and shows a verifiable growth rate.

The growth rate is governed by four parts of GDP. The first is personal consumption, which involves sales to consumers. The next part is investment, such as construction and inventory levels. Government spending forms the third propeller of growth. This manifests more in defense spending (particularly in Nigeria where the government spends more on insurgence and related criminality and social infrastructures. Governments also increase spending to jump-start the economy during a recession. The fourth propeller of growth is trade.

\subsubsection{ECOWAS Sub-Region}

ECOWAS) as at February, 2017 became a 15 member States, eight of these are French-speaking, five are English-speaking, while two are Portuguese-speaking. ECOWAS sub-region consists of the following countries: Benin, Burkina Faso, Cape Verde, Cote D'Ivoire, Gambia, Ghana, Guinea, Guinea Bissau, Liberia, Mali, Niger, Nigeria, Senegal, Sierra Leone and Togo. ECOWAS became a sub-regional bloc in Lagos on $28^{\text {th }}$ 
May, 1975 to integrate economies of the West African countries listed above. The economic community adopted Trade Liberalization Scheme to allow free trade among those member countries (lyoha \& Okim, 2017). Later, the leadership extended ECOWAS agreement by accelerating economic integration and political cooperation, as well. The sub-region is constrained by many problems that relate to capacity to attract external finance on account of corruption and political instability and other factors like poor infrastructures (Musibau et al., 2017).

The fifteen member countries, despite being members of different colonial indoctrinations, shared strong historical, geographical, cultural and economic affiliations. However, these West African countries cut across ethnic and cultural lines, often dividing single ethnic groups between two or more countries. These countries are unrelated in resource endowments, but alike in several respects such as low per capita income, poor state of infrastructural development, heavy indebtedness, high level of corruption, political crises among others (Anifowose, 2016). Another unifying characteristic of ECOWAS is very poor domestic savings culture. The sub-region has been witnessing fluctuations in its commodity prices (particularly oil), depreciating domestic currency and import-export imbalances.

ECOWAS is divided into two sub-regional blocs:

- The West African Economic and Monetary Union (UEMOA) is an organization of eight predominantly French-speaking, countries within the ECOWAS that shares similar traditional practices and currency union. This organization was established in 1994, and they have a common currency known as CFA franc, which is pegged to the euro.

- The West African Monetary Zone (WAMZ) is made up of six English-speaking countries in the subregion. WAMZ was established in 2000 , and ever since has been planning to adopt a common currency known as the eco

ECOWAS operates in three co-official languages, namely: French, English and Portuguese. It consists of two institutions to implement policies: the ECOWAS Commission and the ECOWAS Bank for Investment and Development (EBID) formerly known as the Fund for Cooperation until it was renamed in 2001. The ECOWAS countries appear to be grouped among the poorest sub-regions in the world due to inadequate capital to bridge the gap between savings and investments. Oluwaseyi (2017) opines that external capital flows particularly external debt will solve this long-lasting problem. Some environmental factors like irregular electric supply, corruption and political crises lead to high cost of doing business in the sub-region, which crowds out foreign investment. As a result, the region appears susceptible to interest based capital external debt. In view of this, the sub-region has been exposed to excruciating pains inflicted by rising external debt service can compromise the value of their local currencies, thereby discouraging foreign investments in the sub-region.

\subsection{Theoretical review}

Numerous theories have attempted to explain the causality between foreign debt and economic growth. The theories that have gained recognition of this research are the "dual-gap" and "dependency". These theories are briefly discussed hereunder:

\subsubsection{Dual-gap Theory}

This study adopted dual-gap theory developed by Chenery and Strout (1966) to explain the usefulness of external debt in augmenting a country's domestic savings. Dual-gap theory posits that external debt is important because it fills the funding gaps occasioned by poor savings and investments, as well as low foreign exchange earnings that result from trade imbalances, thereby contributing to economic growth in borrowing jurisdictions. The foregoing claim has been the overriding economic objective of external debt for decades (Arhenful, 2013). This theory recognizes investment as the catalyst for growth, and in developing economies it is not profoundly evident due to their low saving culture; hence the demand for imported capital resources at least to begin with.

In order to ease off the gaps associated with the sub-Saharan Africa, which ECOWAS sub-region is part of, the dual-gap model recommends the need to allow substantial flow of external finance in form of foreign loan to compensate for shortfalls in savings and foreign exchange. In the same vein, pro-dual-gap 
International Journal of Academic Research in Accounting, Finance and Management Sciences

Vol. 10 (1), pp. 172-188, ( 2020 HRMARS (www.hrmars.com)

supporters (Amassoma, 2014; Orji, Uche \& Ilori, 2014) view efficient use of foreign finance as panacea to bridge the dual gaps. 


\subsubsection{Dependency Theory}

Dependency theory was developed by Paul A. Baran in 1957. This theory describes the nature of international relations among countries of the world, stressing that developed countries influence less developed countries through their economic power.

Major assumptions of the theory include that the (i) present underdeveloped state and inequality among countries are essential aspect of these interactions; (ii) wealthy countries oppress and dominate poor countries via media control, politics, economics, education, sport, culture, banking and finance (Utomi, 2014); (iii) resources are evacuated from "periphery" of poor and underdeveloped countries to "core" of rich countries, thereby improving the economic wellbeing of the latter at the expense of the former; (iv) underdeveloped economies not only provide dumping grounds for obsolete technology, but also supply natural resources, cheap labour and markets for developed economies, enhance their living standards.

The theory adherents prescribe foreign assistance in form of loan, aid, investment, as well as unhindered operations of the Multinational Corporations (MNCs) as remedial measures. The state of dependency on technologically advanced countries by Africans is attributed to bad leadership, mismanagement, poor institutional framework, corruption, low level of technology, and lack of close integration (Utomi, 2014). As a result, most needy countries rely on imported products and financial services from Europe, America and China as "lifeline".

\subsection{Empirical review}

This section reviewed numerous works in order to establish a clear perception of our study objective. Those reviewed works were presented according to currency of the works.

Asafo et al. (2019) examined impact of external debt on economic growth in 46 sub-Saharan African countries covering 1990-2017 applying a two-step General Method of Moments (GMM) technique. The result proved that external debt had a negative and significant influence on GDP growth. However, the first lag of external debt variables stimulated GDP growth. It was further discovered that harmful effect of external debt did not preclude rich or poor SSA countries.

Mothibi and Mncayi (2019) employing auto-distributive lag (ARDL) model examined the effect of government debt in South Africa, 1994 to 2017. Findings of this paper indicated that there were long-run casual effect among government debt and government spending, real GDP, inflation and real interest rates with government spending, real GDP and interest rate being the key propeller of public debt in South Africa. Government debt had a negative influence on economic growth and inflation. There were no significant relationships between inflation, real interest rates and government debt in the short-run.

Gövdeli (2019) examined the effect of external debt on economic growth in Turkey adopting annual time series data collected from the World Bank Development Indicators within the period, 1970-2016. ARDL technique was used to estimate the series. In view of this, the finding revealed that external debt exerted a positive influence on economic growth. In contrast openness of economy and consumer price index had a negative impact on economic growth within the sampled period.

Kore (2019) studied external debt and economic growth in 13 emerging economies applying a panel autoregressive distributed lag (ARDL) model over the period 1990-2016. The results revealed that there was no positive effect of external debt on economic growth in the long run. Also, external debt exerted a negative but significant influence on economic growth in the short-run throughout the sample period.

Mazheri and Dahalan (2019) assessed the effect of external debt, interest payments and export earnings on economic growth of Pakistan, 1990-2017 using co-integration analysis. Also unit root test was carried out to ascertain the stationrity of the dataset. Error correction model (ECM) was used as technique of analysis. In short-run the following results emerged: (i) external debt (ED) to GDP had a negative but significant effect on GDP; (ii) external debt to export earnings (EE) ratio exerted a negative but significant influence on GDP, and (iii) interest payments on external debt (IP) to GDP ratio presented insignificant but positive impact on GDP. For long-run period, the results indicated that (i) ED to GDP, ED to EE and IP to GDP ratios showed a negative and non-significant effect on GDP in Pakistan for the described period. It was concluded that independent variable ratios influenced about $56 \%$ of Pakistani economy over the review period. 
Ebhotemhen and Umoru (2019) examined the impact of external debt on agricultural production in Nigeria using annual time series data covering1980 to 2017. The error correction model (ECM) and cointegration test were used to estimate the variables. The finding indicated external debt had a negative effect on agricultural production, implying that external loans for agriculture within period of study were not optimally utilized in line with national objective.

Yusuf (2019) studied the impact of public debt on economic growth in Nigeria, comparing its impact during the military regime with civilian era using ordinary least square (OLS) method. Also, chow test of structural change was used to compare the military and civilian era. It was discovered that public debts during military regimes recorded more impacts on economic growth than civilian administrations.

Seher and Taner (2019) examined the impact of public debt on economic growth in Organization for Economic Cooperation and Development (OECD) using panel threshold regression model to analyze panel data, 2002 to 2016. The outcome proved that effect of public debt on economic growth was linear. The public debt threshold was projected at $99.75 \%$ for OECD countries, but it was non-significant. Public debt to GDP ratio was both below and above this threshold; the effect of public debt on economic growth was negative but significant.

Maitra (2019) studied impact of public debt and foreign aid on selected macroeconomic variables: income, price level and interest rate in Sri Lanka over the period 1980-2000. The study found that public debt in general and foreign debt, in particular, depressed income and stimulated price level. Domestic debt had effect on the price level. Foreign aid, however, had harmful influence on both income and price levels. Foreign debt and aid raised interest rate both in short-run and in long-run, whereas no significant effect of domestic debt on interest rate was traced.

Mohanty and Panda (2019) assessed the macroeconomic effects of public debt in India using a structural vector autoregressive (SVAR) approach from 1980-2017. The specific objectives of study were to investigate impact of several types of public debt on economic growth, investment, interest rate and inflation in India. The results indicated that public debt had an adverse effect on economic growth, positive effect on long-term interest rate and a mixed response (both negative and positive) on investment and inflation in India. Also, domestic debt recorded more unfavourable effect on the economy than external debt in India.

Saungweme and Odhiambo (2019) reviewed the impact of public debt on economic growth in both developing and developed countries. The survey indicated diverse results, and in some cases, inconsistent evidence on the topic studied. Although the majority of the surveyed literature discovered negative outcomes, several other studies found a long-run positive impact. The study also found that a few other studies supported the Ricardian Equivalence theory, which posits non-existent relationship between public debt and economic growth. The paper also discovered growing empirical evidence that supported the threshold effects of public debt on economic growth.

León, Murillo and Hernández (2019) examined the effect of public indebtedness on economic growth in Latin America. The major findings showed that public debt-GDP ratio of 75 per cent decelerated growth, adding that a ratio of 35 per cent promoted the growth volatility. Based on panel autoregressive (VAR) model the study also found that public debt and terms of trade influenced effect of public debt on economic growth. This implies that the more public debt increases, an economy becomes vulnerable in the short term. However, in the long-term the growth was relevant for fiscal sustainability.

Sami and Mbah (2018) studied the impact of government external borrowing on economic growth in Oman. Annual time series data for the periods, 1990-2015 were obtained from the World Bank and the Central Bank of Oman. The paper used ARDL econometric method to estimate the variables. The paper established that external debt had a negative and significant effect on economic growth in Oman within the period studied. Moreover, gross fixed capital had a positive and significant impact on growth performance of Omani economy. The study recommended a more productive use of external debt to run the economy.

Adams and Klobodu (2018) studied the differential effects of capital flows on economic growth in five Sub-Saharan African (SSA) countries from 1970-2014. Applying ARDL model; the findings indicated that in the long-run foreign direct investment (FDI), aid, external debt, and remittances recorded differing effects on economic growth. FDI recorded positive and significant effects in Burkina Faso and negative outcomes in Gabon and Niger; whereas external debt also recorded negative outcomes in the other countries studied. In 
contrast, aid boosted growth in Niger and Gabon, while it constrained growth in Ghana. Remittances equally recorded positive and significant effects in Senegal. Finally, gross capital formation was significant in most of the component countries; the effect of trade was mixed.

Musibau et al. (2018) examined the impact of external debt on economic growth among ECOWAS countries using panel data from 1980 to 2015 . The study adopted panel least square to estimate variables. The result indicated the existence of short and long-run long causality between external debt and economic growth. The study concluded that external debt would promote investments if judiciously used.

Shkolnyk and Koilo (2018) investigated the relationship between foreign debt and economic growth in Ukraine and other emerging economies covering 2006-2016. The study adopted ADL model and correlation techniques. The regression outcomes showed the original values had no significant impact on the estimation of the parameters. The scholars proved that increased level of external debt, in conjunction with macroeconomic instability, hindered economic growth in the study areas. The result also showed a critical level of debt burden for emerging economies, where marginal effect of external debt on economic growth became negative. The outcomes highlighted the significance of the problem of effective public debt management strategy implementation in Ukraine.

Matuka and Asafo (2018) used error correction model and co-integration analysis to assess the impact of external debt on economic growth in Ghana using time series covering 1970 to 2017. The findings revealed that external debt had a positive effect on economic growth in Ghana both in the long-run and short-run. Also, the finding affirmed crowding out effect, debt overhang effect and non-linear effects of external debt on economic growth in Ghana over the studied period.

Senadza et al. (2017) examined the effect of external debt on economic growth in 39 sub-Saharan African countries for the period 1990-2013. The paper applied the General Method of Moments (GMM) technique. Besides finding evidence for a negative effect of external debt on economic growth, the study also discovered no evidence for disproportional relationship between debt and growth. Moreover, it was found that the income per capita dummy was not significant, which implied that being a rich or poor SSA does not change the narrative that external debt hindered economic growth over sampled period.

Jawaid and Saleem (2017) examined the effect of foreign capital inflows measured by FDI, workers' remittances and external debt on economic growth in Pakistan applying annual time series data covering 1976 to 2015. Co-integration results showed foreign capital inflows exerted significant influence on economic growth in the long-run. Ordinary least square results proved that FDI had a significant and negative impact on economic growth, whereas remittances and external debts affected economic growth positively and significantly.

Siddique et al. (2017) assessed impact of external debt on economic growth in Pakistan, 1975-2015. The study adopted ARDL model to estimate the variables after determining the stationary properties of the series. The findings revealed external debt recorded a negative and significant effect on economic growth in Pakistan, whereas human capital and trade were revealed as increasing factors of economic growth in the short and long-run. The paper suggested that export earnings may support economic growth. It is also important to enhance the level of investment and human capital. The Pakistani government should focus on the programme so as to increase inflow of foreign direct investment and reduce the frequency for acquiring external and internal debt. In order to minimize reliance on external debt, there is need to develop local industrial and agriculture sector to improve export profile and decrease imports.

\subsection{Gaps in Knowledge}

Taking the empirical reviews into consideration, some gaps in knowledge were identified: (1) most of the reviewed works unjustifiably applied nominal GDP rather than real GDP or growth rate to represent economic growth. Nominal GDP, which represents the current monetary value of a country's GDP, fail to consider changes in inflation; (2) most data used as basis for making calculations or drawing conclusions lacked currency, and ( 3 there were divergent empirical outcomes of reviewed related research topics, while some recorded positive and significant results, others had negative and non-significant effects due to level of development of the sampled countries, data coverage, methodology applied, and the researchers' choice of control variables, among other factors. 


\section{Methodology of research}

\subsection{Research Design}

Ex-post facto design was adopted for this study because the design relied on historical data, and we neither manipulated nor controlled the relevant explained and explanatory variables studied. Relevant data for this study were obtained from secondary source. Accordingly, datasets for the 15 ECOWAS countries were sourced from the World Development Indicators (2019). The type of data considered fitting for this work was panel data. Panel data possess both time series and cross-sectional dimensions.

\subsection{Model Specification}

For the purpose of achieving desired results, we made use of panel regression and patterned our study in line with the work of Jarju et al. (2016) that assessed the relationship between external debt and economic growth in the West African Monetary Zone (WAMZ) indicated thus:

$$
g_{i t}=\alpha_{0}+\alpha_{1} \text { EXTDEBT }_{i t}+\alpha_{2} \text { EXTDEBT }_{\text {it }}{ }^{2}+\alpha_{3} \text { DEBTSERV }_{i t}+\alpha_{4} \text { GROINV }_{i t}+\alpha_{5} \text { TOTGR }_{i t}+\alpha_{6} \text { OPEN }_{i t}+\alpha_{7} \text { POPGR }_{i t}+\mu_{i t}
$$

Where: $g=$ growth variable to represent real GDP growth rate or real GDP per capita; EXTDEBT = external debt as a percentage of GDP to capture debt stock; DEBTSERV = Total debt service as a little of percentage of GDP (a flow component of debt and a measure of the stock of external debt); GROINV = domestic investment as percentage of GDP to capture the rates of growth in capital as a factor input for production process; TOTGR $=$ Terms of trade measured as ratio of an index of a country's export prices to an index of its import prices; OPEN = Degree of openness measured as ratio of the sum of imports and exports to GDP; POPGR = population growth rate, a proxy for rates of growth in labour as an input for the production process; $\mu=$ error term.

In view of the foregoing model, the variant model estimate for our hypothesis is modified as follows:

$$
R G D P G R_{i t}=\alpha_{0}+\alpha_{1} E X D \_G N l_{i t}+\alpha_{2} E X D S P \_G N l_{i t}+\alpha_{3} G D S \_G D P i t+\mu_{i t}
$$

Where: $\alpha_{0}=$ constant; RGDPGR = real GDP Growth Rate; EXD_GNI = external debt (measured as a ratio to gross national income); EXDSP_GNI = external debt service payments (measured as share of gross national income); GDS_GDP = gross domestic saving (as share of GDP); $\mu=$ error term; $\alpha_{1}-\alpha_{3}=$ coefficients of the independent variables; $i$ and $t$ denote country specific and time respectively. A priori expectation of the coefficients in the model is shown as $\alpha_{1}>0 ; \alpha_{2}<0 ; \alpha_{3}>0$.

\subsection{Technique of Analysis}

The panel least square (PLS) estimation process was applied to ensure proper analysis of our study objective. Individual characteristic of the variables was ascertained with descriptive statistics; the panel unit root test was executed to determine stationary attributes of the series. Our models were further analyzed with both fixed and random effect panel regression estimators, while Hausman test was employed to ascertain the best and appropriate choice between the two. Hausman is a diagnostic test used to choose the most appropriate and efficient model between the fixed effect and the random effect estimators. A 5\% error tolerance level (level of significance) was allowed for this study. Eviews econometric software package for modeling financial data was considered suitable for our panel data analysis. In our thinking, Eviews package appears more suitable and dynamic for secondary data analysis compared to the Statistical Package for Social Sciences (SPSS).

\section{Analysis and interpretations of data}

\subsection{Preliminary Tests}

\subsubsection{Descriptive Statistics}

Table 1. Descriptive Statistics of the panel Data Series

\begin{tabular}{lcccc}
\hline & $\begin{array}{c}\text { RGDPGR } \\
\mathbf{( \% )}\end{array}$ & $\begin{array}{c}\text { EXD } \\
\text { (US\$'BLN) }\end{array}$ & $\begin{array}{c}\text { EXDSP } \\
\text { (US\$'BLN) }\end{array}$ & $\begin{array}{c}\text { GDS } \\
\text { (US\$'BLN) }\end{array}$ \\
\cline { 2 - 5 } Mean & 4.006497 & 103.5951 & 3.454776 & 7.900024 \\
Median & 4.24808 & 66.27429 & 2.371614 & 8.370088 \\
\hline
\end{tabular}




\begin{tabular}{lcccc}
\hline & $\begin{array}{c}\text { RGDPGR } \\
(\%)\end{array}$ & $\begin{array}{c}\text { EXD } \\
\text { (US\$'BLN) }\end{array}$ & $\begin{array}{c}\text { EXDSP } \\
\text { (US\$'BLN) }\end{array}$ & $\begin{array}{c}\text { GDS } \\
\text { (US\$'BLN) }\end{array}$ \\
\cline { 2 - 5 } Minimum & -30.1451 & 4.130462 & 0.101269 & -141.974 \\
Std. Dev. & 4.774027 & 148.2197 & 4.588108 & 20.20243 \\
Skewness & -1.62723 & 4.892354 & 7.145517 & -3.18275 \\
Kurtosis & 16.25946 & 32.12871 & 78.71804 & 23.45714 \\
Jarque-Bera & 3603.826 & 18609.05 & 115285.6 & 8491.762 \\
Probability & 0 & 0 & 0 & 0 \\
Sum & 1859.015 & 49000.47 & 1609.926 & 3507.611 \\
Sum Sq. Dev. & 10552.39 & 10369410 & 9788.591 & 180805.2 \\
Observations & 464 & 473 & 466 & 444 \\
\hline
\end{tabular}

Source: Researchers' computations (2020)

Table 1 presents the descriptive statistics of our panel dataset, and shows that, on the average, real GDP growth (RGDPGR) was $4.01 \%$ and was highest at $26.42 \%$ between 1986 and 2017. External debt as a ratio to gross national income (EXD_GNI) averaged 103.60\%, while the mean of external debt services payments as share of gross national income (EXDSP_GNI) stood at $3.45 \%$ and peaked at $59.67 \%$ during the period. On the other hand, the mean of gross domestic savings as a share of GDP (GDS_GDP) stood at 7.9\%.

\subsubsection{Tests for Stationarity}

Table 2 indicates panel unit root tests:

Table 2. Panel Unit Root Test

\begin{tabular}{lcccccc}
\hline \multicolumn{1}{c}{ Variable } & $\begin{array}{c}\text { Levin, Lin \& } \\
\text { Chu t }\end{array}$ & $\begin{array}{c}\text { Breitung t- } \\
\text { stat }\end{array}$ & $\begin{array}{c}\text { Im, Pesaran } \\
\text { \& Shin W- } \\
\text { stat }\end{array}$ & $\begin{array}{c}\text { ADF - Fisher } \\
\text { Chi-square }\end{array}$ & $\begin{array}{c}\text { PP - Fisher } \\
\text { Chi-square }\end{array}$ & $\begin{array}{c}\text { Order of } \\
\text { Integration }\end{array}$ \\
\hline RGDPGR & $-3.82166^{*}$ & $-2.88789^{*}$ & $-5.42255^{*}$ & $86.4113^{*}$ & $254.393^{*}$ & $\mathrm{I}(1)$ \\
EXD_GNI & $-6.91885^{*}$ & $-5.48599^{*}$ & $-7.16073^{*}$ & $105.291^{*}$ & $430.357^{*}$ & $\mathrm{I}(1)$ \\
EXDSP_GNI & $-10.7623^{*}$ & $-5.01436^{*}$ & $-12.4209^{*}$ & $183.635^{*}$ & $1397.94^{*}$ & $\mathrm{I}(1)$ \\
\hline GDS_GDP & $-4.17303^{*}$ & $-5.48177^{*}$ & $-8.01080^{*}$ & $144.202^{*}$ & $1084.26^{*}$ & $\mathrm{I}(1)$ \\
\hline
\end{tabular}

Source: Researchers' computations (2020)

${ }^{* * *}$ Significant at $1 \%$ and $5 \%$

Results of the panel unit root test are presented in Table 2. Stationarity of the series was tested using five test criteria namely (1) Levin, Lin \& Chu t, (2) Breitung t-stat, (3) Im, Pesaran and Shin W-stat, (4) ADFFisher Chi-square, and (5) PP-Fisher Chi-square. The outcomes reveal that all our panel series are stationary, which entails that our panel series do not have unit root. Based on the results, we therefore conclude that our panel series became stationary after initial differencing (i.e. at order one).

It is not econometrically acceptable to carry out a regression analysis on non-stationary time series data as it would ultimately result in spurious regression results. However, research has also proven that stationarity test on cross-sectional data and pooled data usually enhance the validity and reliability of results; hence our desire to run a pooled unit root test on all our variables with five different criteria.

\subsection{Test of Hypothesis}

The technique of analysis employed in estimating our models is the panel ordinary least square. We primarily estimated the fixed effect (FE) estimator and the random effect (RE) estimator and applied Hausman test to choose the most appropriate model between the two estimators. The pooled least square was also estimated for the benefit of comparison with the two major traditional estimators (FE and RE).

Restatement of hypothesis in null and alternate forms:

$\mathrm{H}_{01}$ : External debt had no positive and significant impact on real GDP growth rate in ECOWAS subregion over the review period. 
$H_{a 1}$ : External debt had a positive and significant impact on real GDP growth rate in ECOWAS subregion over the review period.

Decision Rules:

The decision rules are based on a $5 \%$ probability values and are stated as follows:

Reject null hypothesis if $p$-value $<0.05$, and accept alternate hypothesis

Accept null hypothesis if $p$-value $>0.05$, and reject alternate hypothesis

The panel regression results are shown and analyzed in Table 3:

Table 3. Results of Panel Regression

Dependent Variable: RGDPGR

\begin{tabular}{lcc}
\hline \multicolumn{1}{c}{ Variable } & $\begin{array}{c}\text { Fixed Effect Estimator } \\
\text { [Coefficient] } \\
(\mathbf{p} \text {-value) }\end{array}$ & $\begin{array}{c}\text { Random Effect Estimator } \\
\text { [Coefficient] } \\
(\mathbf{p} \text {-value) }\end{array}$ \\
\hline EXD & {$[-0.011089]$} & {$[-0.010608]$} \\
& $(0.0000)^{*}$ & $(0.0000)^{*}$ \\
\hline EXDSP & {$[0.006432]$} & {$[0.000291]$} \\
& $(0.9013)$ & $(0.9951)$ \\
\hline GDS & {$[-0.037796]$} & {$[-0.030183]$} \\
& $(0.0376)^{*}$ & $(0.0092)^{*}$ \\
\hline Intercept & {$[5.181197]$} & {$[5.094921]$} \\
& $(0.0000)^{*}$ & $(0.0000)^{*}$ \\
\hline Prob (Hausman) & & \\
\hline $\mathbf{R}^{2}$ & 0.710100 & 0.783295 \\
\hline Adjusted R & 0.674421 & 0.717017 \\
\hline DW & 1.918904 & 1.868318 \\
\hline F-statistic & 3.085780 & 13.26615 \\
\hline Prob(F-statistic) & $0.000038^{*}$ & $0.000000^{*}$ \\
\hline
\end{tabular}

Source: Author's Computation (2019).

* and ** Significance at $1 \%$ and $5 \%$

RGDPGR = 5.091 - 1.1 EXD + 0.03 EXDSP - 3.02 GDS

We present in Table 3 the results of our two key estimations consisting of the fixed effect and the random effect estimators. The Hausman test was also conducted to determine which of the two estimators is more appropriate and consistent. The Hausman test has $p$-value $0.6013>0.05$, and thus we are guided to accept the null hypothesis that the preferred model is random effect. In other words, we based our analysis on the random effect (RE) estimator. The results show that external debt (EXD) has a negative and significant impact on real GDP growth rate (RGDPGR). We observed that $1 \%$ change in EXD led to about $1.1 \%$ decline in RGDPGR. On the other hand, external debt services payments (EXDSP) has a positive but insignificant impact on RGDPGR where one percent change in EXDSP brought about $0.03 \%$ increase in RGDPGR. The results also showed that gross domestic savings (GDS) exerted a negative and significant effect on the dependent variable (RGDPGR). It was observed that $1 \%$ change in GDS resulted in $3.02 \%$ decline in RGDPGR.

The $R^{2}$ or Adjusted $R^{2}$ is the coefficient of determination indicates that about $78 \%$ of the variation in RGDPGR is explained by a change in the independent variables. The F-value (13.27), with a probability value $0.000000<0.05$ indicated that the regressors are jointly significant in explaining the dependent variable (RGDPGR). Durbin-Watson test (DW) is approximately 2.0, showing that the Random effect estimator does not have traits of serial correlation.

Decision:

We base our decision on the Random effect estimation, where the coefficient of our main independent variable is negatively signed with $p$-value $0.0000<0.05$. Since the $p$-value is less than $5 \%$ conventional level of significance, we therefore accept the alternate hypothesis and reject the null hypothesis. This means that EXD had significant (but negative) impact on real GDP growth rate. The 
economic implication was that external debt could not be used to forecast improvement or slowdown in economic growth in ECOWAS sub-region over the review period.

Table 4. Country-specific debt-growth nexus in ECOWAS sub-region: A Basis for Comparison

\begin{tabular}{lc}
\hline Cross-Section & Coefficient \\
\hline Benin & -0.319567 \\
Burkina Faso & 0.804019 \\
\hline Cape Verde & -0.244373 \\
\hline Cote d'Ivoire & -0.526268 \\
\hline The Gambia & -0.780931 \\
\hline Ghana & 1.22098 \\
\hline Guinea & 0.436459 \\
\hline Guinea-Bissau & 0.012494 \\
\hline Liberia & 0.486466 \\
Mali & 0.267699 \\
\hline Niger & -0.412666 \\
Nigeria & 1.571299 \\
\hline Senegal & -0.548119 \\
Sierra Leone & -1.238347 \\
\hline Togo & -0.668743 \\
\hline
\end{tabular}

Source: Authors' computations (2020)

Table 4 shows results of individual country relative effects of external debt on economic growth as highlighted in our study objective. The results reveal differing outcomes for each country, which form basis for comparison as can be observed from the Table. Positive and negative effects were linked to diverse magnitudes or degrees of causal effects.

\subsection{Discussion of Results}

Based on the specific objective of our study, which examined the effect of external debt on real GDP growth rate in ECOWAS sub-region, the empirical outcomes of this work were discussed below.

Contrary to a priori expectation that external debt should facilitate economic growth, our results indicated that the major independent variable (external debt) had a negative but significant impact on real GDP growth rate. We observed that $1 \%$ change in external debt led to about $1.1 \%$ decline in real GDP growth rate. On the other hand, external debt service payments had a positive but insignificant impact on real GDP growth rate where $1 \%$ changes in external debt service payments brought about $0.03 \%$ increase in real GDP growth rate. The results equally recorded that gross domestic savings exerted a negative but significant influence on the dependent variable - where $1 \%$ change in gross domestic savings resulted in $3.02 \%$ decline in real GDP growth rate.

The economic implication was, although external debt remains one of the debt instruments through which ECOWAS countries manage their economy so as to achieve desirable macroeconomy, statistically, it could not add up to achieve economic growth in ECOWAS sub-region during the period studied. It failed to improve capacity utilization expected to boost productivity due to reasons not unconnected to governance, corruption, and systemic inefficiency, among others.

The major finding above (external debt had a negative but significant impact on real GDP growth rate) conforms to Asafo et al. (2019) who investigated the impact of external debt on economic growth in 46 sub-Saharan African (SSA) countries, using panel data for a period of 1990-2017, and estimated by twostep general method of moments (GMM). Our major finding also agrees with Senadza et al. (2018) who studied the impact of external on economic growth in 39 SSA countries using panel least square from 1990 to 2013, and estimated by general method of moments (GMM) technique. These works had established that external debt had a negative and significant effect on economic growth in SSA countries during the review period. Our result was further affirmed by Kore (2019) who examined impact of external debt on economic growth in 13 emerging economies using panel data from 1990-2016, as well as Shkolnyk and Koilo (2018) who assessed the relationship between foreign debt and economic growth in Ukraine and other emerging economies for the period 2006 to 2016. Both studies adopted ARDL estimation processes. 
The scholars proved that increases stock of external debt, together with macroeconomic instability, hindered economic growth in those countries. The result also revealed that there was high level of debt burden for emerging economies, where the marginal impact of external debt on economic growth became negative. The outcomes highlighted the significance of the problem of effective public debt management strategy implementation in the sub-region. Above all, these situations have been attributed to ineffective fiscal policy implementations and lack of budget discipline in the ECOWAS sub-region.

Our major finding, however, disagrees with Govdeli (2019) who employed ARDL bounds technique to examine effect of external debt on economic growth in Turkey for the period 1970-2016, as well as Musibau et al. (2018) that studied impact of external debt on economic growth in West African countries from 1980-2015. Also, Anifowose (2016) examined impact of external debt and debt servicing on economic growth of some ECOWAS countries applying time series data covering the period 1970-2008. The econometric model consisted of gross domestic product as explained variable, while external debt stock and debt servicing formed the explanatory variables. The Error Correction Model (ECM) was used to estimate the variables, which provided a useful link between the long-run equilibrium and short-run disequilibrium dynamics. The findings showed that the macroeconomic impact of external debt stock and its servicing varied for different countries among the ECOWAS countries. External debt had a positive influence on economic growth in Benin and Niger, while the impact of external debt negatively affected economic growth in Burkina Faso, Cote d'Ivoire, Gambia, Guinea- Bissau, Nigeria, Sierra-Leone and Togo.

Juxtaposing the sub-regional result of our major independent variable (external debt) with outcome of the country-specifics (in Table 4), external debt had positive effects on economic growth in Burkina Faso, Ghana, Guinea, Guinea Bissau, Liberia, Mali and Nigeria during the review period. This affirms the a priori expectation that external debt should promote economic growth. However, external debt exerted negative effects on economic growth in Benin, Cape Verde, Cote d'Ivoire, The Gambia, Niger, Senegal, Sierra Leone and Togo, which validated sub-regional result in those countries during the review period. It is interesting to note that the studies of Matuka and Asafo (2018) and Ndubuisi (2017) conducted in Ghana and Nigeria respectively affirm our country specific results in respect of Ghana and Nigeria where external debt exerted positive effect on economic growth. Also note that the conflicting empirical results [(between Anifowose (2016) and our country-specific)] presented above could be attributed to a number of reasons, but not limited to differences in sample period, methodology adopted, reliability of data obtained, and/or the phenomena investigated.

\section{Conclusions and Recommendations}

This research assessed impact of capital inflows in ECOWAS sub-region, and related the outcomes to the EXD vs. RGDPGR of 15 West African countries. Data for 15 ECOWAS countries covering 31 years (19862017) were obtained from the Development Indicators as published by the World Bank. Ex-post facto design was adopted because our data were secondary in nature. Individual characteristic of the variables were ascertained with descriptive statistics. The stationarity of our variables was tested using five test criteria, namely: (1) Levin, Lin \& Chu t; (2) Breitung t-stat; (3) Im, Pesaran and Shin W-stat; (4) ADF-Fisher Chi-square, and (5) PP-Fisher Chi-square. The results indicated that all our panel series were stationary after first differencing [(i.e. at order one I(1)], which proved that our panel series did not have unit root. Panel least square (PLS) estimation process was used to analyze our modified models. Our models were further analyzed with both fixed effects and random effects panel regression estimators, using the Hausman test to ascertain the best and appropriate choice between the two. Thus, our analysis was based on the random effects (RE) estimator. A 5\% error tolerance level (level of significance) was allowed for this study. The finding proved external debt had a negative, but significant impact on real GDP growth rate in ECOWAS sub-region.

The implication was that external debt did not improve economic growth in the sub-region during the sample period. This result was attributed to ineffective fiscal policy implementations and lack of budget discipline. Since external debt is a noteworthy debt instrument that can help boost the economies of ECOWAS countries (i) governments of the sub-region must adopt fiscal adjustment mechanisms that can enhance their revenue profiles through improved taxes rather than borrowing to finance deficit and total reliance on primary commodities (usually unprocessed e.g. crude oil, cocoa) for revenue, and (ii) 
government should avoid borrowing as much as possible, but since developing countries need to borrow occasionally to augment domestic savings, borrowing should be made an alternative financing plan when critical projects were being considered. Disbursement of loans should be properly monitored and channeled to targeted viable projects. The major contribution of this study to knowledge was that it made comparative analysis using outcomes of the sub-regional study and the country-specific outcomes of the 15 member countries of ECOWAS employing modified panel regression models to analyze the research objective.

\section{References}

1. Adams, S., \& Klobodu, E. K. M. (2018) Capital flows and economic growth revisited: Evidence from five sub-Saharan African countries. International Review of Applied Economics, 32(5), 620-640.

2. Adejuwon, K. D., James, K. S., \& Soneye, O. A. (2010), Debt burden and Nigeria's development. .Journal of Business and Organizational Development, 2, 102-113

3. Akanni, O. L. (2014), Impact of external debt accumulation and capital flight on economic growth of West African countries. African Economic Research Consortium, 279, 1-40.

4. Aluko, F., \& Arowolo, D. (2010), Foreign aid, the third world's debt crisis and the implication on economic development: The Nigerian experience. African Journal of Political Science and International Relations, 4(4), 120-127.

5. Amassoma, D. (2014). The linkage between foreign aid and economic growth in Nigeria. International Journal of Economic Practices and Theories, 4(6), 1007-1017.

6. Anifowose, O.L. (2016), Impact of External Debt and Debt Servicing on Some ECOWAS Countries Economic Growth. Elixir Financial Management, 91, 38247-38251.

7. Arhenful, P. (2013), Effect of foreign aid on real exchange rate in Ghana. Advances in Management and Applied Economics, 3(5), 151-169.

8. Asafo, S. S., Matuka, A., \& Nyendu, D. (2019). External debt and economic growth: Two-step system GMM evidence for sub-Saharan Africa Countries. International Journal of Business, Economics and Management, 6(1), 39-48.

9. Chenery, H. B., \& Strout, A. M. (1966). Foreign assistance and economic development. The American Economic Review, 679-733.

10. Ebhotemhen, W., \& Umoru, D. (2019). External debt and agricultural production in Nigeria. SRIWIJAYA International journal of Dynamic Economics and Business, 3(1), 1-14.

11. Ekanayake, E. M., \& Chatrna, D. (2010), Effect of foreign aid on economic growth in developing countries. Journal of International Business and Cultural Studies, 1-13.

12. Esezobor, E. A. (2009), International finance, $2^{\text {nd }}$ edition. Sabo-Yaba, Lagos: CIBN Press Ltd.

13. Gohar, M., Bhutto, N.A. \& Butt, F. (2012). The impact of external debt servicing on the growth of low-Income countries. Proceedings of $2^{\text {nd }}$ International Conference on Business and Management. Sukkur Institute of Business Administration.

14. Gövdeli, T. (2019), External debt and economic growth in Turkey: An empirical analysis. Sosyoekonomi, 27(40), 119-130.

15. Iyoha, M., \& Okim, A. (2017), Impact of trade on economic growth in Economic Community of West African States (ECOWAS) countries: Evidence from panel data. Central Bank of Nigeria Journal of Applied Statistics, 8(1)

16. Jawaid, S. T., \& Saleem, S. M. (2017). Effect of foreign capital inflows on economic growth of Pakistan. Journal of Transnational Management, 22(2), 121-149.

17. Kore, M. A. G. (2019). External debt and economic growth in emerging economies. International Economic Journal.

18. León, J. M. G., Murillo, J. W. R., \& Hernández, E. A. R. (2019). Public Debt and Stability in Economic Growth: Evidence for Latin America. International Journal of Economics and Financial Issues, 9(4), 137-147.

19. Maitra, B. (2019). Macroeconomic impact of public debt and foreign aid in Sri Lanka. Journal of Policy Modeling, 1-28. 
20. Matuka, A., \& Asafo, S. S. (2018). Exteral debt and economic growth in Ghana: A co-integration and vector error correction analysis. MPRA Munich Personal RePEc Archive

21. Mazheri, M. A., \& Dahalan, J. (2019). Effect of external debt, interest payments and export earnings on economic growth in Pakistan. International Research Journal of Marketing \& Economics, 6(3), 16-31.

22. Mohammad, M. (2018), Impact of foreign capital inflows on economic growth on selected African countries. African Journal of Economic and Management Studies, 9(14), 523-536.

23. Mohanty, R. K., and Panda, S. (2019). How does public debt affect the Indian macro-economy? A structural VAR approach. Working Paper No. 245

24. Mothibi, L., \& Mncayi, P. (2019). Investigating the key drivers of government debt in South Africa: A post-apartheid analysis. International Journal of eBusiness and eGovernment Studies, 2(1), 16-33.

25. Musibau, H. O., Mahmood, S., Ismail, S., Shamsuddin, Z., \& Rashid, N. (2018). Does External Debt Cause Economic Growth? An Experience from ECOWAS Member Countries. International Journal of Academic Research in Business and Social Sciences, 8(11), 1256-1264.

26. Obiechina, M. E., \& Ukeje, E.U. (2013). Economic growth, capital flows, foreignexchange rate, export and trade openness in Nigeria. International Journal of Economics and Management Sciences, 2(9), 141-152.

27. Oluwaseyi, M. U. (2017), Does external debt cause economic growth? An experience from ECOWAS member countries. International Academic Conference on Business and Economics (IACBE 2017) held at Universiti Sultan Zainal Abidin, Terengannu, Malaysia.

28. Onyekwelu, U. L., Okoye, E., \& Ugwuanyi, U.B. (2014). External debts management strategies in developing economies: An impact assessment on selected economic indices of Nigeria. International Journal of Economics and Finance, 6(8).

29. Orji, A., Uche, A. S., \& Ilori, E. A. (2014). Foreign capital inflows and growth: An empirical analysis of WAMZ experience. International Journal of Economics and Financial Issues, 4(4), 971-983.

30. Osinubi, T. S., \& Olaleru, E. (2006). Budget deficits, external debt and economic growth in Nigeria Applied Econometrics and International Development, 6(3), 159-185.

31. Raheem, I. D., \& Adeniyi, O. A. (2015), Capital inflows and outflow and economic growth in SubSaharan Africa. International Journal of Economics and Business Research, 10(1), $66-80$.

32. Sami, A. K., \& Mbah, S. A. (2018), External Debt and Economic Growth: The Case of Emerging Economy. Journal of Economic Integration, 33(1), 1141-1157.

33. Saungweme, T., Odhiambo, N. (2019). Impact of public debt on economic growth: A review of contemporary literature. The Review of Black Political Economy, 45(4).

34. Seher, G. T., \& Taner, S. (2019). Is there a threshold effect of public debt on economic growth? Advances in Finance, Accounting, and Economics.

35. Senadza, B., Fiagbe, A. K., \& Quartey, P. (2017). Effect of external debt on economic growth in Sub-Saharan Africa. International Journal of Business and Economic Sciences Applies Research, 11(1), 61-69.

36. Shkolnyk, I., \& Koilo, V. (2018). The relationship between external debt and economic growth: empirical evidence from Ukraine and other emerging economies. Investment Management and Financial Innovations, 15(1), 387-400.

37. Siddique, H. M. A., Ullah, K., \& Haq, I. U. (2017). External Debt and Economic Growth Nexus in Pakistan. International Journal of Economics and Empirical Research, 5(2), 73-77.

38. Sulaiman, L. A., \& Azeez, B. A. (2012). Effects of external debt on economic growth of Nigeria. Journal of Economics and Sustainable Development, 3(8), 1-21.

39. Utomi, O. W. (2014). Impact of external debt on economic growth in Nigeria (1980-2012) Bachelor of Science (B.SC) Degree Project Report presented to the Department of Economics and Development Studies, Covenant University, Ota, Nigeria, 1-58.

40. Yusuf, I. (2019). Public debt and economic growth in Nigeria: A comparative analysis of the military and civilian era. Proceedings of Annual International Academic Conference, 267-276. 